\title{
A Tanzanian perspective on the nutrition transition and its implications for health
}

\author{
TN Maletnlema* \\ Child Growth Promotion Union, PO Box 20265, Dar es Salaam, Tanzania
}

\begin{abstract}
Objective: The purpose of this paper is to describe social and economic changes related to shifts in diet and activity and to present prevalences for chronic diseases associated with the nutrition transition.

Design: Observations about social changes are descriptive, based on published reports and personal observations. Prevalence and trends data are based on a Ministry of Health published report and, for infants and toddlers, on primary data.

Setting: Disease prevalences for diabetes mellitus and hypertension are taken from four sites, representing underdeveloped, semi-developed and well-developed rural communities and Dar es Salaam, the largest city in Tanzania. The prevalences of underweight and overweight for infants and toddlers are taken from a small periurban clinic in Tanzania.

Subjects: Adults over 15 years of age are included in the prevalence data for chronic disease. The urban sample is stratified by occupation and ethnicity. The data for infants and toddlers include newborns to those aged 23 months.

Results: An increase in the prevalence of diabetes and hypertension was observed. Simultaneously, there have been rapid changes in diet and physical activity related to urbanisation and modernisation. The highest prevalences for diabetes and hypertension were among high-ranking executives.

Conclusion: The increase in chronic disease could be related to the rise in the number of high-ranking executives. Simultaneously, per capita income has gone down, and malnutrition prevalence has risen. Programmes are being developed to simultaneously monitor trends in overweight while preventing protein-energy malnutrition and micronutrient deficiency.
\end{abstract}

Slimness, often associated with AIDS today, has never been admired in Tanzania, but obesity is looked upon with such admiration that in the past the man with the fattest wife was highly respected because he had the most beautiful woman. Previously, women rarely grew fat because they always worked too hard. Hence, the traditional practice of resting and fattening girls indoors, in preparation for engagement and marriage. It is not surprising that the traditional preference for being heavy exists alongside Western standards. In the case of beauty pageants, when Western standards of moderate slimness were adopted, the organisers began a special show for heavier ladies. The changes in diet-related chronic disease, described later in the paper, are best understood in the context of significant social and economic changes that have occurred over the four decades since gaining independence. The most significant changes directly related to nutrition are changes in education, food production, alcohol, smoking, drug abuse, urbanisation, reduced energy expenditure, adoption of the Free Trade Market Policy, psychological tension and HIV.

\section{Social factors related to the nutrition transition}

\section{Education and culture}

Although falling now, during the last two decades of the 20th century Tanzania achieved an adult literacy of over $90 \%$, a primary school enrolment of about 90\%, and a secondary school enrolment of $4-5 \%{ }^{1}$. In the past, better education and Westernisation have been related to several factors that directly influence diet-related chronic disease, such as bottle-feeding infants instead of breast-feeding, eating refined cereals instead of lightly milled, eating ice cream instead of fruit, and using a personal car instead of public transportation or walking.

Diet, food production, availability and presentation Drought and irregular rains have contributed to mild to severe food shortages, which forced rural communities to migrate to urban areas where imported cereals are available. Popular traditional foods like millet are being replaced by rice and maize and imported foods are often used to solve food shortage problems. The cumulative 
effect of this is a gross deterioration of local production. Maize and rice have become 'cash crops' and compete with imported cereals, which are often cheaper but nutritionally far inferior. Although local entrepreneurs have introduced weaning and processed foods based on cereals and legumes, only the rich can afford them. Before 1960 Tanzanians rarely processed food in mills or factories; most foods were cooked in the natural form. Today, a large percentage of foods are processed and packaged, particularly in the urban areas. Processed foods include cereals, meat and fish full of fat and salt, and many items high in sugars and starches. Popular, cheap snacks are doughnuts, cakes and sugary drinks. Salted nuts, sugary milk products, chocolate, candies and ice cream are available to richer people. Soft drinks are widely available and bottled drinking water is now sold because tap water is not safe and is often muddy.

Available diet data reflect the disparity in nutritional status by income. Tanner and Lukmanji ${ }^{2}$ estimated the total energy intake of the urban population in Dar es Salaam to be $1600 \mathrm{kcal}$ for the low-income group and $3000 \mathrm{kcal}$ or more for the high-income group. Fats contributed 43\% (mainly animal fats), proteins 17\% and carbohydrates (cereals, sugar, potatoes and alcohol) 40\% to total energy intake in the high-income group. For the middle- and lower-income groups, fats contributed 15\%, proteins $15 \%$ and carbohydrates $70 \%$.

\section{Alcobol, smoking and drug abuse}

Traditional Tanzanian alcoholic drinks were made from partly germinated cereal flours, honey or fruits. The germinated cereals used for beer making also contain a good amount of the $\mathrm{B}$ vitamins, minerals and carbohydrates. The final brew is often a very diluted porridge with a low-to-moderate alcohol content. Since Westernisation, consumption of industrial beer, wines and hard liquor has risen considerably. Unfortunately, modern alcoholic drinks contain high quantities of mainly alcohol. Excessive alcohol drinking has been directly related to obesity and diabetes among government executives ${ }^{3}$. Although cigarettes and drugs are not food, their use is closely related to eating practices and the money spent displaces food. The prevalence of smoking among females is $1.5 \%$ in Dar es Salaam, $19.7 \%$ in Kilimanjaro and $15.8 \%$ in Morogoro; the prevalence among males is higher: $21.7 \%$ in Dar es Salaam, 55.8\% in Kilimanjaro and 60.3\% in Morogoro ${ }^{4}$. Many urban youths in Tanzania have been lured into drugs, which affects their health and has even worse effects on food availability for the families involved.

\section{Urbanisation}

Most of the people in urban and some rural areas walk less now than they did two decades ago. However, for most rural people, food has become scarce and more expensive, and water and firewood require more walking to find. Simultaneously urbanisation is rising: the population living in urban areas rose from 5\% in 1960 to $25 \%$ in 1998 , a fivefold increase ${ }^{1}$. As a result, many good dietary practices have been replaced by harmful ones. As newcomers flock into the cities, they find snacks like ice cream to be much better than the traditional roast banana or cassava. The few successful urban immigrants grow fat on urban snacks and foods, while most barely get enough to eat.

\section{Free market policy}

Traders associated with larger transnational companies are doing very well, while others struggle and many go bankrupt. For example, when the price of coffee (1998) was 1600 Tanzanian shillings (TSh) per pound (1600 TSh is approximately US\$2.00), many new farmers were given loans on the condition that most of their crop would be coffee. This led to increased production and this year the price plummeted to about 600 TSh per pound ${ }^{5}$. Furthermore, the International Monetary Fund (IMF) and bank policies prefer those who have their own initial funds; those who have no funds are rarely considered for loans and the Free Trade System is corrupted by bribery in favour of the rich. The result is too much food for a few and too little for the majority.

\section{Psychological tension and HIV}

Psychological tension continues to rise for most people due to rising costs of food and fuel, unemployment, HIV infection, increases in social service charges, and devaluation or termination of their job, land ownership, social benefits or subsidies. These changes, together with HIV, have affected income, food availability and consumption, and thus created new problems. HIV alone has caused changes in breast-feeding and food production, and loss of family income, and created new problems such as care for infected children and orphans.

\section{Results of the nutrition transition}

Although the social changes described above have contributed to changes in the prevalence of noncommunicable diseases, this paper presents results only for diabetes mellitus, hypertension, malnutrition and obesity. Most of the information in this paper is derived from a recent study, Policy Implications of Adult Morbidity and Mortality ${ }^{4}$. This was a bilateral study, funded jointly by the government of Tanzania and the United Kingdom Department for International Development.

\section{Diabetes mellitus}

Many of those who have taken interest in the disease think that the prevalence of diabetes mellitus began to rise after the $1960 s^{6-14}$. While the existence of diabetes was questioned in decades prior to the 1960s, now most African cities have diabetes clinics. The sudden increase of diabetes cases is viewed as a result of two factors. First, 
before the 1960s, few Tanzanians utilised hospitals. Only severe diabetes cases came to hospitals, often suffering or dying from other acute illnesses. Diagnosis was not easy and blood tests were rarely available. After independence, more or less free hospital services were provided by the government. Today, particularly in the urban centres, almost all people depend on hospital services and diabetes diagnosis is easier. Second, urbanisation and modernisation have rapidly changed dietary and physical activity patterns. Moving from a village to an urban area is a shift from hard work and a traditional diet with fresh foods, plenty of roughage, little sugar, fat and salt to less work and mostly processed and refined foods, little roughage, plenty of sugar, fat and salt.
The prevalence of diabetes among ordinary Tanzanians is, on average, one of the lowest in the world. Studies during the $1980 \mathrm{~s}^{12}$ found a prevalence of $0.2 \%$ of diabetes in the rural population and $1.1 \%$ in ordinary urban Africans in Dar es Salaam. Table 1 shows the prevalence of diabetes in various groups of Tanzanians. It can be seen that the highest socio-economic groups have the highest diabetes prevalence, which is $12 \%$ among high executives in government and private company positions. The Ministry of Health experts involved in the national study ${ }^{4}$ concluded that among certain well-defined groups, which may be occupational, the prevalence of diabetes is higher than among Europeans. The report also concluded that these groups have experienced changes in physical

Table 1 Prevalence of diabetes in adults, selected areas and populations; contribution of diabetes all causes of death

\begin{tabular}{|c|c|c|c|}
\hline \multirow[b]{2}{*}{ Area/adults aged $30-64$ years } & \multirow[b]{2}{*}{$\begin{array}{l}\text { Prevalence } \\
\quad(\%)\end{array}$} & \multicolumn{2}{|c|}{$\begin{array}{l}\text { Contribution of diabetes to all } \\
\text { causes of death in Tanzania }\end{array}$} \\
\hline & & Male (\%) & Female (\%) \\
\hline Mara, Tanzania (under-developed, rural) & 0.6 & & \\
\hline Morogoro, Tanzania (semi-developed, rural) & 0.8 & 0.7 & 0.2 \\
\hline Kilimanjaro, Tanzania (well-developed, rural) & 0.7 & 2.1 & 1.8 \\
\hline Dar es Salaam (DSM), Tanzania (largest city) & 1.1 & 2.6 & 1.7 \\
\hline Mapuche, India & 1.0 & & \\
\hline Da Quing, China & 2.0 & & \\
\hline Rural Melanesians & 2.0 & & \\
\hline Rural Indians & 3.0 & & \\
\hline Russians & 3.0 & & \\
\hline Polish & 4.0 & & \\
\hline Rural Polynesians & 4.0 & & \\
\hline African nuns (DSM) & 4.3 & & \\
\hline US Whites & 7.0 & & \\
\hline US Hispanics & 7.0 & & \\
\hline Brazilians & 8.0 & & \\
\hline Ithna-asheri Asians & 8.8 & & \\
\hline Maltese & 9.0 & & \\
\hline Tunisians & 9.0 & & \\
\hline Hindu Asians (DSM) & 9.8 & & \\
\hline African priests (DSM) & 10.0 & & \\
\hline US Blacks & 11.0 & & \\
\hline Bohra Asians (DSM) & 11.6 & & \\
\hline African high executives & 12.2 & & \\
\hline Chinese Mauritians & 13.0 & & \\
\hline Urban Micronesians & 14.0 & & \\
\hline Puerto Ricans, NY & 15.0 & & \\
\hline South African Indians & 17.0 & & \\
\hline Naurans & 42.0 & & \\
\hline Pima Indians & 50.0 & & \\
\hline
\end{tabular}

Source: Ministry of Health, $1997^{4}$.

Urban Africans: ordinary Africans who came to live in Dar es Salaam temporarily or permanently. Some urban Africans are fairly rich but the majority are quite poor. To survive they have to work very hard with little pay or else turn to crime.

African nuns: Roman Catholic Church female leaders and their equivalent in other churches. They are more sedentary than other African women, and have greater access to food and also alcohol.

Ithna-asheri Asians, Hindu Asians, Bohra Asians: Asians of different ethnic groups with very different cultures. Some only intermarry among themselves. In general, these ethnic groups are relatively affluent, and have sedentary occupations.

African priests: top leaders of the churches. A few women are now included in this group and Moslem leaders are also becoming more prevalent. Again, the problem is food availability and sedentary work. This problem does not arise in churches where the priests are not paid very well and do a lot of physical labour.

African high executives: the leaders of the country. A book has been written about them and their lifestyle with the aim of reducing non-communicable disease (NCD) among them. As stated for a definition of this group, 'they are the people who are praised for every good that happens in a country and equally blamed for every evil. They are in constant mental strain.' The majority have a very poor lifestyle involving long hours of work, overeating, drinking and lack of sleep. 
activity, an increase in energy and fat, and an increase in body weight. Although not specifically addressed in the report, these groups have simultaneously experienced a rise in income and social status. Table 1 shows that the most affected Tanzanians, the high executives, compare very closely with Afro-Americans. Additionally, Table 1 shows the contribution of diabetes mellitus to all causes of death among adults in Dar es Salaam, Kilimanjaro and Morogoro (also see Aspray et al. ${ }^{15}$ ). The experts also concluded that diabetes affects more Tanzanian men than women, is increasing, probably even among ordinary urban Tanzanians, and that Asians have higher prevalence rates than Africans. Table 2 shows that, in terms of impaired glucose tolerance (IGT) and diabetes, men are more affected than women ${ }^{16,17}$.

As elsewhere, genetic as well as environmental factors play major roles in causing diabetes. The auto-antibodies to islet cell antigens (ICA) that are present in almost all Caucasians with insulin-dependent diabetes mellitus (IDDM) were found in only $20 \%$ of Tanzanians with IDDM $^{18}$. This suggests other causative factors among the Tanzanian Africans. Malnutrition-related diabetes mellitus is said to arise when chronically malnourished individuals consume high levels of dietary cyanide (poorly processed cassava), but this was not confirmed in the Tanzanian study ${ }^{4}$. Furthermore, the proportion of all diabetic patients with IDDM and non-insulin-dependent diabetes mellitus (NIDDM) has remained constant and no increase in diabetes was found in the malnourished groups.

\section{Hypertension}

The hypertension definition used here is that of the World Health Organization (WHO) ${ }^{19}$ from 1990, i.e. a systolic pressure at or above $160 \mathrm{mmHg}$ and a diastolic pressure at or above $95 \mathrm{mmHg}$. The history of hypertension is similar

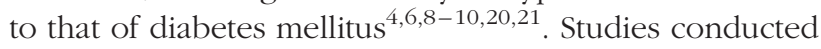
in the $1980 \mathrm{~s}$ showed a prevalence of $3-7 \%$ for rural

Table 2 Age and gender distribution of patients with diabetes and impaired glucose tolerance (IGT) in the total population

\begin{tabular}{|c|c|c|c|c|c|c|}
\hline \multirow[b]{2}{*}{ Age (years) } & \multirow[b]{2}{*}{ Sex } & \multirow{2}{*}{$\begin{array}{l}\text { Total } \\
\text { group }\end{array}$} & \multicolumn{2}{|c|}{ Diabetes } & \multicolumn{2}{|c|}{ IGT } \\
\hline & & & Number & (\%) & Number & (\%) \\
\hline \multirow[t]{2}{*}{$15-24$} & Males & 714 & 4 & 0.6 & 34 & 4.8 \\
\hline & Females & 1064 & 1 & 0.1 & 45 & 4.2 \\
\hline \multirow[t]{2}{*}{$25-34$} & Males & 532 & 3 & 0.6 & 18 & 3.4 \\
\hline & Females & 825 & 3 & 0.4 & 46 & 5.6 \\
\hline \multirow[t]{2}{*}{$35-44$} & Males & 448 & 1 & 0.2 & 29 & 6.5 \\
\hline & Females & 616 & 6 & 1.0 & 61 & 9.9 \\
\hline \multirow[t]{2}{*}{$45-54$} & Males & 376 & 5 & 1.3 & 29 & 7.7 \\
\hline & Females & 411 & 2 & 0.5 & 40 & 9.7 \\
\hline \multirow[t]{2}{*}{$55-64$} & Males & 278 & 7 & 2.5 & 35 & 12.6 \\
\hline & Females & 295 & 3 & 1.0 & 44 & 14.9 \\
\hline \multirow[t]{2}{*}{$65+$} & Males & 275 & 9 & 3.3 & 40 & 17.1 \\
\hline & Females & 249 & 9 & 3.6 & 47 & 16.1 \\
\hline \multirow[t]{2}{*}{ Total } & Males & 2623 & 29 & 1.1 & 192 & 7.3 \\
\hline & Females & 3460 & 24 & 0.7 & 276 & 8.0 \\
\hline
\end{tabular}

Source: Data extracted from McLarty et al. ${ }^{16}$ and Kitange et al. ${ }^{17}$ communities and 10\% for urban Dar es Salaam. The prevalence of hypertension among high executives was $14.3-48.9 \%$.

Figure 1 shows hypertension prevalences in various groups of the Tanzanian population. The figure reveals that the highest prevalence is among high executives, $48.9 \%$. These may be related to the rapid changes in lifestyle experienced by the high executives. The basic cause of hypertension is not easy to pinpoint, but several factors have been associated and noted in Tanzania such as high dietary salt, low dietary potassium, alcohol consumption, obesity, mental stress, and maternal undernutrition in pregnancy ${ }^{22}$.

\section{Protein-energy malnutrition and anaemia}

A few urban studies of the nutritional status of children indicate that malnutrition of the protein energy type and anaemia are increasing in urban areas. Protein-energy malnutrition such as kwashiorkor and marasmus has been common for many decades. Surveys conducted two to three decades ago showed a prevalence of 30-60\% of moderate-to-severely underweight children. By 1985 , Tanzania had established good maternal and child health services and the United Nations Children's Fund (UNICEF) reported a falling prevalence ${ }^{1}, 27 \%$ by 1998 . However, this improvement could be the result of free medical services given to children and mothers during the 1990s. However, today it is increasingly difficult for the government to offer free services and many cannot pay. Iron deficiency anaemia is also common in Tanzania ${ }^{23-27}$ and is often associated with hookworm infection and schistosomiasis. Mtimavalye $^{28}$ reported that $83 \%$ of pregnant mothers admitted at the national Muhimbili obstetric wards were anaemic.

\section{Obesity}

During the 1980s obesity was already common, particularly in diabetic patients. McLarty et al. ${ }^{16}$ observed that diabetic patients aged 30 years or older in Dar es Salaam were more obese than non-diabetics of the same age. High executives, mainly represented by members of parliament, were five times more obese than other urban Africans, but 30 times more when compared with rural Africans. Lukmanji et al. ${ }^{29}$ concluded that many people are unaware of their own body weight. Fifty-eight per cent of the staff of a large organisation in Dar es Salaam was found to be overweight and almost one-third of them had no idea of their weight status. Last year, at a small peri-urban Child Health Clinic, both obesity and marasmus occurred among 2-year-old children in the same poor community. Some mothers overfeed their children with high-energy foods (tinned cereals, full cream milk, sugar or honey, butter, porridge, etc.) and their own milk with the belief that fatness means well being. 


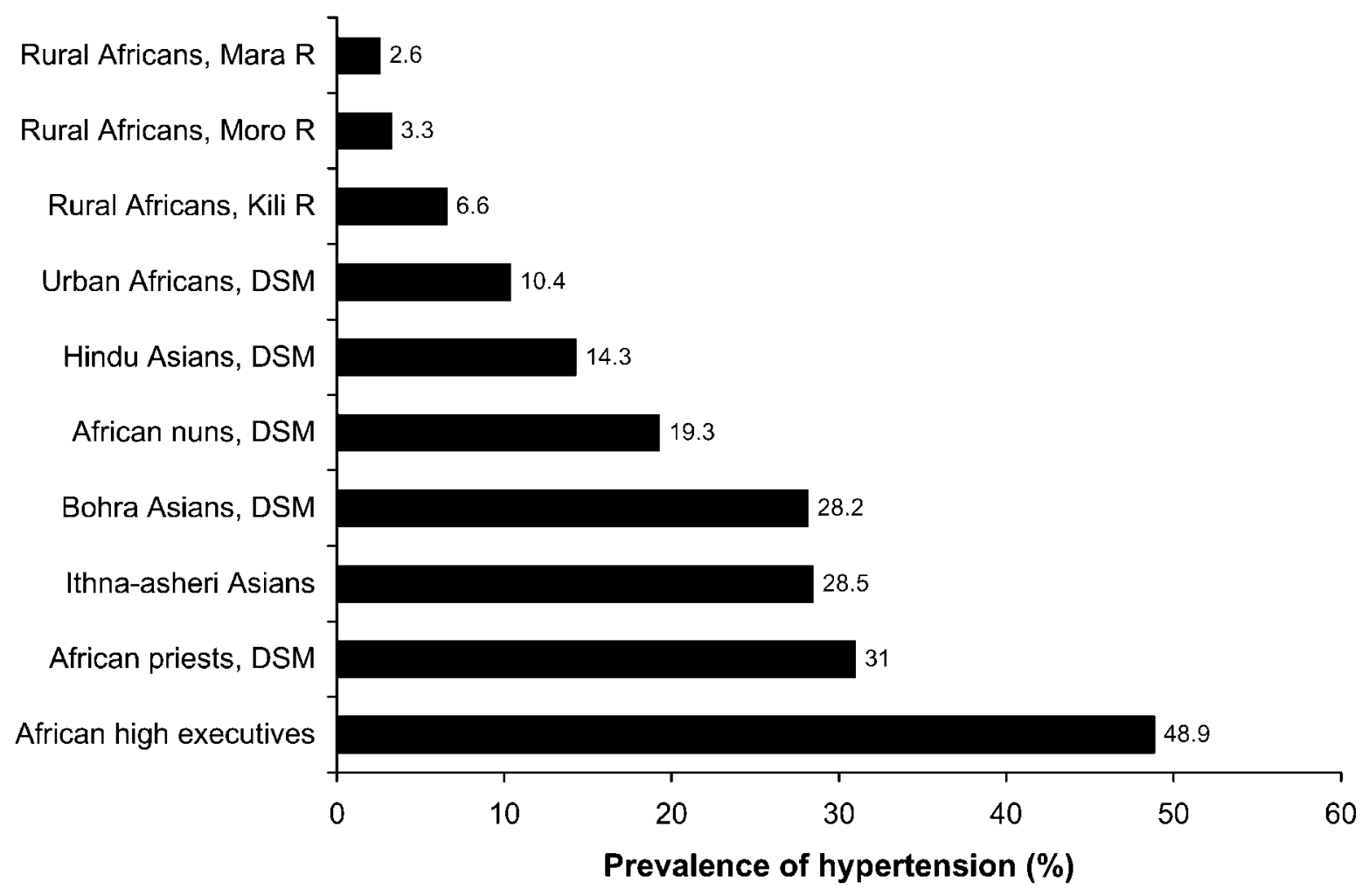

Fig. 1 Prevalence of hypertension in various adult populations aged 15 years and above (DSM - Dar es Salaam; Mara R - Mara region (under-developed, rural); Moro R - Morogo region (semi-developed, rural); Kili R - Kilimanjaro region (well-developed, rural)). Source: Ministry of Health ${ }^{4}$

\section{Conclusion}

Tanzania is experiencing globalisation, which has a noticeable effect on food availability, dietary habits and health, particularly in the cities. Obesity and other noncommunicable diseases are just beginning to draw attention in Tanzania. The survey by the Ministry of Health was the first of its kind and what official action will be taken remains to be seen. In 1974 a small book outlining the dangers and prevention of obesity was published $^{30}$. It aroused controversy related to the belief that fat people are healthy or rich exploiters of the poor. However, economic changes have led to an increase in the number of high-ranking executives. As in many other countries in Africa, this change means a growing disparity between rich and poor. Furthermore, unpredictable weather, falling cash crop prices and siphoning of production has lowered the per capita income from US\$280 in 1981 to US\$210 in 1997. This means less food and lower dietary consumption. A small group of Tanzanians have now established a non-governmental organisation (Child Growth Promotion Union, CGPU) as a part of a larger adult health-monitoring clinic. If funds can be generated for the clinics, it will be possible to observe large urban communities for a long time. At the same time, the generation and dissemination of health education to prevent deterioration or improve the present status for those affected by protein-energy malnutrition and micronutrient deficiency will also be possible. Although the need for combining projects on overnutrition and undernutrition - as pointed out by Doak et al. ${ }^{31}$ - was arrived at for different reasons, in Tanzania this author reached a similar conclusion based on a very simple argument of the 'haves' and the 'have nots' combining efforts to achieve a common goal.

\section{References}

1 Grant JP. The State of the World Children. UK: UNICEF/ Oxford University Press, 1990.

2 Tanner M, Lukmanji Z. Food consumption patterns in a rural Tanzanian community. Acta Tropica 1987; 44: 229-44.

3 Lukmanji Z. Dietary management of diabetes mellitus in Africa. In: Albert KGMM, DeFronzo RA, Keen H, Zimmet P, eds. International Textbook of Diabetes Mellitus. UK: John Wiley \& Sons Ltd, 1992; 711-8.

4 Ministry of Health (MOH). Policy Implications of Adult Morbidity and Mortality. Dar es Salaam: MOH, 1997.

5 Anon. International commodity prices. Business Times, 2001

6 Cole AEE. Some observations on heart diseases in Dar es Salaam. E. Afr. Med. J. 1959; 10: 538-41.

7 Haddock DRW. Diabetes mellitus and its complications in Dar es Salaam. E. Afr. Med J. 1964; 41: 145-55.

8 Anon. Heart diseases - main causes of death in hospitals, Annual Report. Daily News, 1966.

9 Nhonoli AM. Heart diseases in Dar es Salaam. E. Afr. Med.J. 1968; 45: 118.

10 Kalluvya S. Stroke in the Africans at Muhimbili Medical Centre. Dissertation submitted for MMed, University of Dar es Salaam, Tanzania, 1984. 
11 Ahren B. Diabetes mellitus at a rural hospital in Northwestern Tanzania. Trop. Geog. Med. 1986; 36: 237-42.

12 Swai ABM, McLarty DG. Diabetes in Tanzania. Tanzania Med.J. 1990; 7: 670-84.

13 Ministry of Health (MOH). Health Profile for Tanzania. Dar es Salaam: MOH, 1991.

14 Alberti H, Swai ABM, Craven J, McLarty DG. Trends in diseases admission and deaths in church hospitals in Tanzania, 1971-1985. Trop. Doctor 1991; 21: 129-30.

15 Aspray TJ, Mugusi F, Rashid S, Whiting D, Edwards R, Alberti KG, Unwin NC. Essential Non-Communicable Disease Health Intervention Project. Rural and urban differences in diabetes prevalence in Tanzania: the role of obesity, physical inactivity and urban living. Trans. Roy. Soc. Trop. Med. Hygiene 2000; 94(6): 637-44.

16 McLarty DG, Pollit C, Swai ABM. Diabetes in Africa. Diabet. Med. 1990; 7: 670-84.

17 Kitange HM, Swai AB, Masuki G, Kilima PM, Alberti KG, McLarty DG. Coronary heart disease risk factors in subSaharan Africa: studies in Tanzanian adolescents. J. Epidemiol. Community Health 1993; 47(4): 303-7.

18 McLarty DG, Athaide I, Bottazzo GF, Swai ABM, Alberti KGMM. Islet cell antibodies are not specifically associated with insulin-dependent diabetes in Tanzanian Africans. Diabetes Res. Clin. Pract. 1990; 9: 219-24.

19 World Health Organization (WHO). Diet, Nutrition and the Prevention of Chronic Diseases. Geneva: WHO, 1990.

20 McLarty DG, Black J, Lewanga M, Livoga E. Policy Implications of Adult Morbidity and Mortality, 1994; 243.
21 Edwards R, Unwin N, Mugusi F, Whiting D, Rashid S, Kissima J, Aspray TJ, Alberti KG. Hypertension prevalence and care in an urban and rural area of Tanzania. J. Hypertens. 2000; 18(2): $145-52$.

22 Barker DJP. Blood Pressure. Mothers, Babies and Disease in Later Life. London: BMJ Publishing Group, 1994; 53-64.

23 Meredith JS, Eyakuze VM. Anaemias, children and adults in Dar es Salaam. E. Afr. Med.J. 1962; 39: 250.

24 Rowland HAK. Anaemia in Dar es Salaam and methods for its investigation. Trans. Roy. Soc. Trop. Med. Hygiene 1966; 60(2): 143-69.

25 Forsyth DM. Anaemia in Zanzibar. Trans. Roy. Soc. Trop. Med. Hygiene 1970; 64: 601-6.

26 Vaugham JP, Menu JP, Kihama F. Anaemia in a coastal area of Tanzania. E. Afr. Med.J. 1973; 50(2).

27 Kavishe FP. Nutritional Anaemia in Tanzania: A Review. Tanzania Food and Nutrition Centre Report No. 738. Tanzania Food and Nutrition Centre, 1982.

28 Mtimavalye LAR. Anaemia in pregnancy at Muhimbili Medical Centre, Dar es Salaam. Proc. Assoc. Surg. E. Afr. $1978 ; 1$.

29 Lukmanji Z, Mrisho F, Moore S. The health status of members of parliament in Tanzania. Unpublished

30 Maletnlema TN. Are You Too Fat? Nairobi, Kenya: East African Literature Bureau, 1974.

31 Doak CM, Adair LS, Monteiro C, Popkin BM. Overweight and underweight coexist within households in Brazil, China and Russia. J. Nutr. 2001; 130: 2965-71. 